\title{
Agrococcus baldri sp. nov., isolated from the air in the 'Virgilkapelle' in Vienna
}

\footnotetext{
${ }^{1}$ Institut für Mikrobiologie und Genetik, Universität Wien, A-1030 Wien, Austria

${ }^{2}$ Institut für Bakteriologie, Mykologie und Hygiene, Veterinärmedizinische Universität, A-1210 Wien, Austria

${ }^{3}$ DSMZ - Deutsche Sammlung von Mikroorganismen und Zellkulturen $\mathrm{GmbH}$, D-38124 Braunschweig, Germany

${ }^{4}$ Institut für Angewandte Mikrobiologie, JustusLiebig-Universität, D-35392 Giessen, Germany

${ }^{5}$ Institut Mediterrani d'Estudis Avancats and Departament de Biologia Ambiental, Universitat de les Illes Balears (CSIC-UIB), E-07071 Palma de Mallorca, Spain
}

\author{
Christian Zlamala, ${ }^{1,2}$ Peter Schumann, ${ }^{3}$ Peter Kämpfer, ${ }^{4}$ \\ Ramon Rosselló-Mora, ${ }^{5}$ Werner Lubitz ${ }^{1}$ and Hans-Jürgen Busse ${ }^{1,2}$ \\ Author for correspondence: Hans-Jürgen Busse. Tel: + 431250772119 . Fax: + 431250772190.
e-mail: Hans-Juergen.Busse@vu-wien.ac.at
}

Five coccoid, Gram-positive strains were isolated from the air of the 'Virgilkapelle' in Vienna. A representative of these five strains, $\mathrm{V}-10 \mathbf{8}^{\mathrm{T}}$, shared 99.0 and 98.4\% 16S rDNA sequence similarity, respectively, with Agrococcus jenensis DSM 9580' and Agrococcus citreus DSM 12453'. Colonies of the five strains were white when grown in the dark and turned yellow in the light. The strains displayed highly similar biochemical and physiological characteristics and showed only small differences in their protein patterns obtained after SDS-PAGE. Based on Fourier-transform infra-red (FT-IR) spectra, the five strains were grouped together and separated from the other members of the genus, $A$. jenensis and $A$. citreus. Chemotaxonomic characteristics analysed from selected members of the five isolates, including polar lipids, quinone systems, polyamine patterns, cell wall composition and fatty acid profiles, were in good agreement with those of the two species of the genus Agrococcus described to date. The G+C content of the genomic DNA was determined to be within the narrow range of 73.8-74.9 mol\%. The results of DNA-DNA hybridization with $A$. citreus DSM $12453^{\top}$ and $A$. jenensis DSM 9580', as well as differences in biochemical/physiological characteristics, peptidoglycan composition, fatty acids, polar lipid profiles and FT-IR spectra, demonstrated that the five isolates represent a novel species of the genus Agrococcus. The name Agrococcus baldri sp. nov. is proposed for the novel species, of which strain V-108 (= DSM $14215^{\top}$

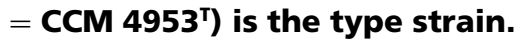

Keywords: Agrococcus baldri sp. nov., 16S rDNA sequence, chemotaxonomy, biochemical/physiological traits

\section{INTRODUCTION}

In a project concerning bacterial colonization and biodiversity, two experimental wall paintings were exposed in the chapels 'Virgilkapelle' in Vienna and the 'Katharinenkapelle' in the castle Herberstein (Styria, Austria). The wall paintings had been constructed using the same materials and had been treated equally. In order to study the influence of airborne bacteria on the colonization of the wall paintings, the biodiversity among airborne bacteria collected at the two locations was studied.

Among the airborne strains collected in the 'Virgilkapelle' underneath the Stephansplatz in

Abbreviation: FT-IR, Fourier-transform infra-red.

The GenBank accession number of the 16S rDNA sequence of Agrococcus baldri V-108 ${ }^{\top}$ is AJ309928.
Vienna, five coccoid, yellow-pigmented, airborne bacteria were isolated that showed photochromogenic behaviour. Characterization of these strains demonstrated that they are members of the genus Agrococcus, which so far consists of two species, Agrococcus jenensis and Agrococcus citreus. Strains of A. jenensis have been isolated from compost soil and sandstone (Groth et al., 1996), whereas A. citreus was isolated from a medieval wall painting in the 'Katharinenkapelle' inside the castle Herberstein (Wieser et al., 1999). Here, we present evidence that the five airborne strains represent a single novel species of the genus Agrococcus.

\section{METHODS}

Bacterial strains and cultural conditions. The five strains V$108^{\mathrm{T}}, \mathrm{V}-50, \mathrm{~V}-64, \mathrm{~V}-98$ and V-109 were isolated from the air of the 'Virgilkapelle' in Vienna using an air sampler (Biotest 
RCS Plus). The strains were collected on CasMM agar (Altenburger et al., 1996). CasMM strips were incubated at room temperature. After 4 days, single colonies were transferred to PYES agar [ $3 \mathrm{~g}$ peptone from casein $1^{-1}, 3 \mathrm{~g}$ yeast extract $1^{-1}, 2 \cdot 3 \mathrm{~g}$ disodium succinate $1^{-1}, 15 \mathrm{~g}$ agar $1^{-1}$ (all from Merck), $\mathrm{pH}$ 7.2] and incubated at room temperature.

Morphological, biochemical and physiological characteristics. Cell morphology was determined by phase-contrast microscopy of cultures of different ages. Colony morphology was studied with a stereo microscope. Gram-staining and the $\mathrm{KOH}$ test were performed as described previously (Moaledji, 1986). Utilization of organic acids and carbohydrates was studied in the medium described by Kämpfer $e t$ al. (1991). Acid production from carbohydrates was tested using Phenolred-Bouillon (Merck) with the carbohydrates added to a concentration of $7 \cdot 5 \mathrm{~g}^{-1}$. Nitrate reduction was tested with nitrate broth (Merck), urease activity with ureaindole medium (bioMérieux), indole production, motility and hydrogen sulfide production with SIM agar (Oxoid) and methyl red and Voges-Proskauer reactions with VP-MR agar (Oxoid). Oxidase activity was tested with Bactident oxidase strips (Merck). All tests were carried out according to the instructions of the manufacturers. Catalase production was tested by the method of Gledhill \& Casida (1969). Hydrolysis of casein, hippurate, Tween 20 and Tween 80 was tested as described previously (Gordon et al., 1973; Isenberg, 1992; Cowan \& Steel, 1974). Hydrolysis of starch and tyrosine was tested by adding double-concentrated nutrient agar (Gordon et al., 1973) to equivalent and separately autoclaved amounts of $10 \%$ potato starch solution and $1 \%$ tyrosine solution in water, respectively. Growth at 4, 28, 37 and $42{ }^{\circ} \mathrm{C}$ was tested on PYES agar. $\mathrm{NaCl}$ tolerance was investigated on PYES agar supplemented with 2, 4, 6.5 and $10 \% \mathrm{NaCl}$. Microaerobic growth was studied on tryptic soy agar (TSA) in an anaerobic jar using an atmosphere consisting of $5 \% \mathrm{H}_{2}, 5 \% \mathrm{CO}_{2}$ and $90 \% \mathrm{~N}_{2}$, as recommended by Fox et al. (1994).

16S rDNA sequence analysis. Two loops of biomass were scraped off the agar plates, suspended in $100 \mu$ sterile water and lysed by repeated cycles of freezing in liquid nitrogen and thawing at $50{ }^{\circ} \mathrm{C}$. The DNA contained in $15 \mu \mathrm{l}$ of the supernatant after centrifugation was used as the template for PCR amplification. 16S rDNA was amplified by the PCR using the universal primers 27f and 1492r (Lane, 1991). Amplification products were purified by precipitation with polyethylene glycol (Wieser et al., 1999). Purified PCR products were sequenced directly at the Service Department of the Vienna Biocenter (MIG-BASE) on a LI-COR $4000 \mathrm{~L}$ sequencer, as outlined by Middendorf et al. (1992). Fluorescently labelled primers $27 \mathrm{f}$ and $1492 \mathrm{r}$ were used (Lane, 1991). The derived sequence was aligned and compared with other bacterial $16 \mathrm{~S}$ rDNA sequences available in the EMBL database using the Wisconsin package (GCG, 1995).

DNA isolation and characterization. Isolation of DNA from acetone-pre-washed biomass and DNA-DNA hybridization were performed as described previously (Lind \& Ursing, 1986; Ziemke et al., 1998). The $\mathrm{G}+\mathrm{C}$ content was determined as described previously (Cerdà-Cuéllar et al., 1997).

Chemotaxonomic investigations. Menaquinones were extracted and analysed as described previously (Tindall, 1990). Polar lipids were extracted and analysed by TLC according to Ventosa et al. (1993). Cellular fatty acid methyl esters were extracted and analysed according to Osterhout et al. (1991) and Wieser \& Busse (2000). Detection of the diagnostic cell wall diamino acid was performed by the method of Schleifer (1985). Analysis of the cell wall amino acids was done as described by Groth et al. (1997). Extraction of polyamines and detection of their patterns were performed as described by Altenburger et al. (1997). For Fourier-transform infra-red (FT-IR) analysis, strains were grown on PYES agar at $28{ }^{\circ} \mathrm{C}$ for $48 \mathrm{~h}$. One loopful of cells was resuspended in $80 \mu \mathrm{l}$ deionized water and an aliquot of $35 \mu \mathrm{l}$ was applied to a pre-defined sample area on a zinc selenite optical plate. The samples were dried under reduced pressure to give a homogeneous film. The IR spectra were recorded in transmission mode between wave numbers 3000 and $699 \mathrm{~cm}^{-1}$ in an FT-IR spectrometer type IFS 28/B (Bruker) as described by Helm et al. (1991a, b). Data acquisition and analysis were carried out using the oPUS 3.0 software for bacterial identification from the same manufacturer. Mean spectra were calculated from six independent measurements. First derivatives of the spectra were compared with the hierarchical cluster analysis methods implemented in opUs 3.0.

SDS-PAGE. The protein patterns of strains V-108 ${ }^{\mathrm{T}}, \mathrm{V}-50, \mathrm{~V}-$ 64, V-98 and V-109 were investigated by whole-cell-extract SDS-PAGE (Altenburger et al., 1996).

\section{RESULTS AND DISCUSSION}

\section{Morphological, physiological and biochemical characteristics}

Colonies of the five isolates were light yellow when grown in the light and white when grown in the dark. They were opaque and convex with glistening surfaces, $2-7 \mathrm{~mm}$ in diameter. Colony margins were entire on nutrient agar. Cells of the isolates were irregular coccoid to rod-shaped, $0 \cdot 7-1 \cdot 0 \mu \mathrm{m}$ wide by $1 \cdot 1-1 \cdot 7 \mu \mathrm{m}$ long. Cells occurred singly, in pairs or occasionally in irregular clusters. They were non-motile. A mycelial growth phase was not observed. The five isolates showed Gram-positive behaviour in staining and $\mathrm{KOH}$ test. They grew best on complex organic media such as TSA at temperatures ranging from 18 to $28{ }^{\circ} \mathrm{C}$ and in the presence of $4 \% \mathrm{NaCl}$. Weak growth was observed at 4 and $37{ }^{\circ} \mathrm{C}$. No growth occurred at $42{ }^{\circ} \mathrm{C}$ or in the presence of $10 \% \mathrm{NaCl}$ or under microaerobic conditions. Biochemical and physiological properties of the five isolates are summarized in Table 1. Among 108 biochemical and physiological characteristics tested, these five strains showed variable results in 17 traits.

\section{S rDNA sequencing and DNA-DNA relatedness}

Analysis of the $16 \mathrm{~S}$ rDNA of strain $\mathrm{V}-108^{\mathrm{T}}$ resulted in a fragment of 1400 bases (positions 50-1469, Escherichia coli numbering; Brosius et al., 1978). Sequence comparison with corresponding sequences (positions 158-1392, E. coli numbering) showed that strain $\mathrm{V}-108^{\mathrm{T}}$ shared the highest similarities with $A$. jenensis DSM $9580^{\mathrm{T}}(99 \cdot 0 \%)$ and $A$. citreus DSM $12453^{\mathrm{T}}(98.4 \%)$. The genus Agrococcus constitutes a separate lineage within the family Microbacteriaceae (Park et al., 1993; Rainey et al., 1994; Groth et al., 1996; Stackebrandt et al., 1997; Suzuki et al., 1997; 
Table 1. Physiological and biochemical properties of Agrococcus baldri sp. nov., A. citreus and $A$. jenensis

+ , Positive; -, negative; d, some strains positive. Symbols indicate results that are not in line with those reported previously for $A$. jenensis (Groth et al., 1996) (†) and/or A. citreus (Wieser et al., 1999) (†). All eight strains were negative for decomposition of casein, $\dagger$ gelatin, Tween 80 and urea, acid production from D-glucose, D-trehalose, D-galactose, D-mannose, $\$$ D-ribose, $\$ \mathrm{D}$-lactose, D-melibiose, D-inulin, $\uparrow \mathrm{D}$-xylose, $\$ \mathrm{D}$-raffinose, $m y o$-inositol, dulcitol and sorbitol, utilization of $p$ arbutin, D-melibiose, salicin, adonitol, $i$-inositol, maltitol, acetate, $\$$ propionate, adipate, azelate, citrate, glutarate, itaconate, mesaconate, pyruvate, suberate, L-alanine, $\beta$-alanine, L-aspartate, Lhistidine, L-leucine, L-ornithine, L-phenylalanine, L-serine, L-tryptophan, 3-hydroxybenzoate, 4hydroxybenzoate and phenylacetate and hydrolysis of $p$-nitrophenyl ( $\mathrm{pNP}) \beta$-D-

galactopyranoside, pNP $\beta$-D-glucuronide, 2-deoxythymidine-5' - pNP phosphate, L-alanine $p$ nitroanilide ( $\mathrm{pNA}$ ), L-glutamate- $\gamma$-3-carboxy pNA and L-proline pNA. All eight strains were negative in the Voges-Proskauer, methyl red, oxidase and indole tests, as well as in production of $\mathrm{H}_{2} \mathrm{~S}+t$ and nitrate reduction. All eight strains were positive for decomposition of potato starch and hippurate, $\dagger+$ acid production from $D$-sucrose, $\dagger+$ L-rhamnose and D-mannitol, hydrolysis of $\mathrm{pNP} \alpha$-D-glucopyranoside and $\mathrm{pNP}$ phenylphosphonate and production of catalase. All eight strains grew in the presence of 2 and $4 \% \mathrm{NaCl}$, but not $10 \% \mathrm{NaCl}$. All eight strains grew well at $28^{\circ} \mathrm{C}$ and weakly at 4 and $37^{\circ} \mathrm{C}$, but not at $42{ }^{\circ} \mathrm{C}$.

\begin{tabular}{|c|c|c|c|}
\hline Characteristic & A. baldri $(n=5)$ & A. $\operatorname{citreus}(n=1)$ & A. jenensis $(n=2)$ \\
\hline \multicolumn{4}{|l|}{ Utilization of: } \\
\hline$N$-Acetyl D-galactosamine & + & - & - \\
\hline L-Arabinose & - & + & - \\
\hline D-Cellobiose & + & + & - \\
\hline D-Fructose & + & + & - \\
\hline D-Galactose & $\mathrm{d}(4 / 5)^{a *}$ & + & - \\
\hline Gluconate & + & + & - \\
\hline D-Glucose & + & + & - \\
\hline D-Mannose & + & + & - \\
\hline D-Maltose & + & + & - \\
\hline L-Rhamnose & + & + & - \\
\hline D-Ribose & + & + & - \\
\hline Sucrose & $\mathrm{d}(4 / 5)^{b}$ & + & - \\
\hline D-Trehalose & + & + & - \\
\hline D-Xylose & - & + & - \\
\hline D-Mannitol & $d(1 / 5)^{c}$ & - & - \\
\hline D-Sorbitol & $\mathrm{d}(1 / 5)^{d}$ & - & - \\
\hline Putrescine & $\mathrm{d}(4 / 5)^{a}$ & - & - \\
\hline cis-Aconitate & $\mathrm{d}(1 / 5)^{d}$ & - & - \\
\hline trans-Aconitate & $d(1 / 5)^{c}$ & - & - \\
\hline 4-Aminobutyrate & + & - & - \\
\hline Fumarate & $\mathrm{d}(4 / 5)^{e}$ & - & - \\
\hline DL-3-Hydroxybutyrate & $\mathrm{d}(2 / 5)^{f}$ & + & - \\
\hline DL-Lactate & $d(4 / 5)^{e}$ & + & - \\
\hline L-Malate & $d(4 / 5)^{e}$ & - & $-\dagger$ \\
\hline Oxoglutarate & $\mathrm{d}(3 / 5)^{g}$ & + & - \\
\hline L-Proline & + & + & - \\
\hline \multicolumn{4}{|l|}{ Hydrolysis of: } \\
\hline pNP $\beta$-D-glucopyranoside & - & + & + \\
\hline bis-pNP phosphate & $\mathrm{d}(2 / 5)^{f}$ & + & + \\
\hline pNP phosphorylcholine & - & - & $\mathrm{d}^{h}$ \\
\hline \multicolumn{4}{|l|}{ Acid production from: } \\
\hline L-Arabinose & - & + & + \\
\hline Maltose & $\mathrm{d}(4 / 5)^{i}$ & - & - \\
\hline Glycerol & $\mathrm{d}(4 / 5)^{i}$ & $-\ddagger$ & $-\dagger$ \\
\hline
\end{tabular}


Table 1 (cont.)

\begin{tabular}{|lccc|}
\hline Characteristic & A. baldri $(\boldsymbol{n}=\mathbf{5})$ & A. citreus $(\boldsymbol{n}=\mathbf{1})$ & A. jenensis $(\boldsymbol{n}=\mathbf{2})$ \\
\hline Decomposition of: & & & \\
Aesculin & - & + & + \\
Tyrosine & $\mathrm{d}(4 / 5)^{i}$ & + & + \\
Tween 20 & - & - & - \\
Growth in the presence of & $\mathrm{d}(2 / 5)^{k}$ & & \\
$6.5 \% \mathrm{NaCl}$ & & & \\
\hline
\end{tabular}

* Strain-dependent results are indicated as: $a, \mathrm{~V}-50$ negative; $b, \mathrm{~V}-108^{\mathrm{T}}$ negative; $c, \mathrm{~V}-108^{\mathrm{T}}$ positive; $d$, V-109 positive; $e, \mathrm{~V}-109$ negative; $f, \mathrm{~V}-108^{\mathrm{T}}$ and $\mathrm{V}-64$ positive; $g, \mathrm{~V}-98$ and $\mathrm{V}-109$ negative; $h, A$. jenensis DSM 9996 positive; $i$, V-98 negative; $j$, A . jenensis DSM $9580^{\mathrm{T}}$ positive; $k, \mathrm{~V}-64$ and V-109 positive.

$\dagger$ Data not in line with Groth et al. (1996).

\$Data not in line with Wieser et al. (1999).

Wieser et al., 1999) of the Actinobacteria. The sequence similarities of $\mathrm{V}-108^{\mathrm{T}}$ to other species of the family Microbacteriaceae were in the range $91 \cdot 0-94 \cdot 0 \%$. These data demonstrate clearly that strain $\mathrm{V}-108^{\mathrm{T}}$ belongs to the genus Agrococcus.

Almost identical protein patterns obtained after SDSPAGE (results not shown) indicated that the five strains are members of a single species. DNA reassociation values of $\mathrm{V}-108^{\mathrm{T}}$ with the other four strains were in the range $95.0-100 \%$, confirming that they are members of a single species. A relatively close relationship of the five isolates to $A$. jenensis DSM $9580^{\mathrm{T}}$ was indicated from DNA relatedness values between 61 and $69 \%$, whereas values of only $30-40 \%$ were detected with $A$. citreus DSM $12453^{\mathrm{T}}$. These data indicate that the five strains are separate from $A$. citreus but closely related to $A$. jenensis. The $\mathrm{G}+\mathrm{C}$ content of the genomic DNA of isolate $\mathrm{V}-108^{\mathrm{T}} \mathrm{DNA}$ was determined to be $74.8 \mathrm{~mol} \%$. The other four strains were shown to have genomic DNA G $+\mathrm{C}$ contents of $73 \cdot 8-74.9 \mathrm{~mol} \%$.

\section{Chemotaxonomic characteristics}

Comparison of FT-IR spectra revealed a high degree of similarity between strains V-108 ${ }^{\mathrm{T}}$, V-50, V-64, V-98 and $\mathrm{V}-109$, as indicated from their clustering and separation from $A$. jenensis DSM $9580^{\mathrm{T}}$, A. jenensis DSM 9996 and $A$. citreus DSM $12453^{\mathrm{T}}$ (Fig. 1 ). These data confirm not only the results from DNA relatedness and protein patterns, which demonstrate that the five isolates are members of a single species, but also the suitability of FT-IR spectra for species affiliation within this group of bacteria. The major menaquinones detected in strain $\mathrm{V}-108^{\mathrm{T}}$ were $\mathrm{MK}-11$ $(41 \%)$ and MK-12 (47\%). In addition, small amounts of MK-10 (9\%) and MK-9 (3\%) were found. A similar menaquinone system was also detected for strain V-64. The characteristic cell wall diamino acid was diaminobutyric acid. In addition, alanine, glycine and aspartic and glutamic acids were detected.

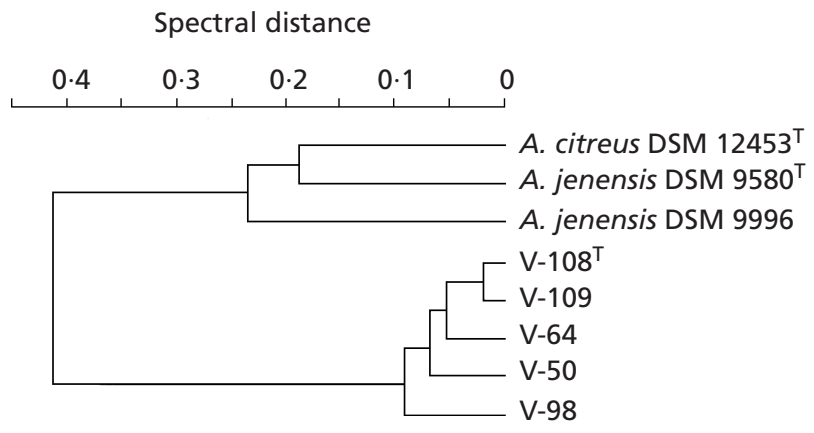

Fig. 1. Average linkage dendrogram based on the distances of first derivatives of FT-IR spectra (frequency ranges $\left.3000-2800 \mathrm{~cm}^{-1} ; 1201-900 \mathrm{~cm}^{-1} ; 901-699 \mathrm{~cm}^{-1}\right)$.

Aspartic acid was found to be the amino-terminal amino acid of the interpeptide bridge. The presence of diaminobutyric acid as a diagnostic cell wall diamino acid is found in several taxa within the family Microbacteriaceae, including the genera Clavibacter, Rathayibacter, Cryobacterium, Agromyces, Agrococcus, Leucobacter and Leifsonia, and also in the misnamed species 'Brevibacterium helvolum' (Collins \& Jones, 1980; Davis et al., 1984; Döpfer et al., 1982; Evtushenko et al., 2000; Groth et al., 1996; Sasaki et al., 1998; Suzuki et al., 1997; Takeuchi et al., 1996; Zgurskaya et al., 1992, 1993). Like A. citreus DSM $12453^{\mathrm{T}}$, the peptidoglycan of isolate $\mathrm{V}-108^{\mathrm{T}}$ contained no threonine, while this amino acid was reported to be present in the cell wall of $A$. jenensis DSM $9580^{\mathrm{T}}$ (Groth et al., 1997). Strain V-108 ${ }^{\mathrm{T}}$ showed a polyamine pattern with the single major compound spermine $\left.[0 \cdot 34 \mu \mathrm{mol} \text { (g dry weight })^{-1}\right]$. This polyamine pattern has been reported for $A$. jenensis DSM $9580^{\mathrm{T}}$ and $A$. citreus DSM $12453^{\mathrm{T}}$ only (Altenburger et al., 1997; Wieser et al., 1999).

Diphosphatidylglycerol and phosphatidylglycerol were found to be predominant in polar lipid extracts of strains $\mathrm{V}-108^{\mathrm{T}}, \mathrm{V}-64$ and $\mathrm{V}-98$. In addition, two 
Table 2. Fatty acid composition of $A$. baldri, $A$. citreus and $A$. jenensis

Strains: 1-5, A. baldri strains V-108 ${ }^{\mathrm{T}}$ (1), V-50 (2), V-64 (3), V-98 (4) and V-109 (5); 6, A . jenensis DSM 9580 (data from Groth et al., 1996); 7, A . citreus DSM $12453^{\mathrm{T}}$ (data from Wieser et al., 1999).

\begin{tabular}{|c|c|c|c|c|c|c|c|}
\hline Fatty acid & 1 & 2 & 3 & 4 & 5 & 6 & 7 \\
\hline $\mathrm{i}-\mathrm{C}_{14: 0}$ & & & & & & $0 \cdot 6$ & $0 \cdot 6$ \\
\hline $\mathrm{C}_{14: 0}$ & & & & & & $0 \cdot 3$ & $0 \cdot 3$ \\
\hline $\mathrm{i}-\mathrm{C}_{15: 0}$ & $5 \cdot 7$ & $5 \cdot 5$ & $4 \cdot 7$ & $6 \cdot 8$ & $5 \cdot 8$ & $12 \cdot 2$ & $10 \cdot 0$ \\
\hline $\mathrm{i}-\mathrm{C}_{15: 1}$ & & & & & & 1.9 & $5 \cdot 6$ \\
\hline ai- $C_{15: 0}$ & $44 \cdot 9$ & $42 \cdot 3$ & $42 \cdot 3$ & $48 \cdot 3$ & $49 \cdot 0$ & $57 \cdot 8$ & $53 \cdot 1$ \\
\hline $\mathrm{C}_{15: 0}$ & & & & & & & $0 \cdot 1$ \\
\hline $\mathrm{i}-\mathrm{C}_{16: 0}$ & $7 \cdot 1$ & $6 \cdot 3$ & $7 \cdot 0$ & $8 \cdot 8$ & $8 \cdot 1$ & $12 \cdot 6$ & $12 \cdot 0$ \\
\hline$C_{16: 0}$ & $3 \cdot 0$ & $3 \cdot 2$ & $2 \cdot 8$ & $3 \cdot 0$ & $2 \cdot 7$ & $2 \cdot 0$ & $1 \cdot 7$ \\
\hline$C_{16: 1}$ & & & & & & & $0 \cdot 2$ \\
\hline $\mathrm{i}-\mathrm{C}_{17: 0}$ & $1 \cdot 5$ & $1 \cdot 8$ & $1 \cdot 2$ & $1 \cdot 7$ & $1 \cdot 7$ & 1.9 & $1 \cdot 7$ \\
\hline $\mathrm{C}_{17: 1}$ & & & & & & & $0 \cdot 1$ \\
\hline ai $-C_{17: 0}$ & $24 \cdot 3$ & $23 \cdot 7$ & $24 \cdot 6$ & $26 \cdot 0$ & $28 \cdot 0$ & $9 \cdot 3$ & $13 \cdot 2$ \\
\hline $\mathrm{C}_{18: 0}$ & & & & & & $0 \cdot 1$ & $0 \cdot 2$ \\
\hline $\mathrm{C}_{18: 1}$ & & & & & & $0 \cdot 1$ & $0 \cdot 1$ \\
\hline
\end{tabular}

unknown glycolipids and one unknown polar lipid were detected. One of these unknown glycolipids was found neither in $A$. jenensis DSM $9580^{\mathrm{T}}$ nor in $A$. citreus DSM $12453^{\mathrm{T}}$. Predominant fatty acids were ai$\mathrm{C}_{15: 0}$ and ai- $\mathrm{C}_{17: 0}$, and $\mathrm{i}-\mathrm{C}_{16: 0}$ and $\mathrm{i}-\mathrm{C}_{15: 0}$ were present in significant amounts (Table 2). These fatty acid profiles differed significantly from those of $A$. jenensis DSM $9580^{\mathrm{T}}$ in the contents of $\mathrm{i}-\mathrm{C}_{15: 0}, \mathrm{i}-\mathrm{C}_{16: 0}$ and ai$\mathrm{C}_{17: 0}$.

These chemotaxonomic characteristics of strain V$108^{\mathrm{T}}$ and selected strains from the group of isolates were in good agreement with the characteristics reported for other members of the genus Agrococcus and are useful for distinction from other diaminobutyric acid-containing taxa (Groth et al., 1996; Altenburger et al., 1997; Wieser et al., 1999), but they also suggested that the isolates belong to a separate species.

\section{Taxonomic considerations}

Whereas DNA relatedness clearly demonstrated that the five isolates do not belong to the species $A$. citreus, the values of DNA-DNA hybridization with $A$. jenensis DSM $9580^{\mathrm{T}}$ were only slightly below the threshold value of $70 \%$ DNA relatedness considered for species delineation (Wayne et al., 1987). However, the five strains could be distinguished easily from $A$. jenensis DSM $9580^{\mathrm{T}}$ on the basis of several characteristics. They differed from A. jenensis DSM $9580^{\mathrm{T}}$ in 16 biochemical properties, peptidoglycan composition, polar lipid pattern and fatty acid profiles. Inclusion of the five isolates into an emended species $A$. jenensis appears not to be justified, since this would create a species indistinguishable from $A$. citreus. Thus, it becomes evident that the five strains $\mathrm{V}-108^{\mathrm{T}}, \mathrm{V}-50$, V-64, V-98 and V-109 represent a novel species of the genus Agrococcus, which can be distinguished from the other two species of the genus. Here, we propose the name Agrococcus baldri sp. nov. for the novel species.

\section{Description of Agrococcus baldri sp. nov.}

Agrococcus baldri (bal'dri. N.L. gen. n. baldri of Baldr, ancient German god of light, referring to the photochromogenic behaviour).

Cells are irregular spherical, ovoid or rod-shaped. The cells vary in size from 0.7 to $1.0 \mu \mathrm{m}$ wide by 1.1 to $1.7 \mu \mathrm{m}$ long. Cells occur singly, in pairs or in small, irregular clusters. They are Gram-positive and nonmotile. Endospores are not observed. Colonies are slightly convex and smooth. Colony diameters on TSA are $2-7 \mathrm{~mm}$. The colour of the colonies on nutrient agar is light yellow when grown in the light and white when grown in the dark. Aerobic. Catalase is produced. Oxidase-negative. Nitrate is not reduced to nitrite. Other biochemical characteristics are given in Table 1. The cell wall diamino acid is diaminobutyric acid; additionally, alanine, glycine and glutamic and aspartic acids are found. No threonine is present. The polar lipid profile is composed of diphosphatidylglycerol, phosphatidylglycerol, two unknown glycolipids and one unknown polar lipid. Fatty acid profile consists of the predominant compounds ai- $\mathrm{C}_{15: 0}$ and ai- $\mathrm{C}_{17: 0}$, and $\mathrm{i}-\mathrm{C}_{16: 0}$ and $\mathrm{i}-\mathrm{C}_{15: 0}$ are present in significant amounts. The quinone system consists of the major menaquinones MK-11 and MK-12. Spermine is the predominant compound in the polyamine pattern. The $\mathrm{G}+\mathrm{C}$ content is $73.8-74.9 \mathrm{~mol} \%$ (HPLC).

The type strain, $\mathrm{V}-108^{\mathrm{T}}\left(=\mathrm{DSM} 14215^{\mathrm{T}}=\mathrm{CCM}\right.$ $4953^{\mathrm{T}}$ ), was isolated from the air in the 'Virgilkapelle' in Vienna, Austria. Other strains of this species are V-64 (= DSM $14216=$ CCM 4954), V-50, V-98 and V-109.

\section{ACKNOWLEDGEMENTS}

This work was supported by a grant from the Austrian Fonds zur Förderung der Wissenschaftlichen Forschung (P12820 MOB). We are grateful to Hans Trüper for advice in nomenclatural problems and to Christian Radax for support in FT-IR analyses. The research of R. R.-M. was supported by the Spanish Ministry of Science and Technology with the grant BOS2000-1123-C02-01.

\section{REFERENCES}

Altenburger, P., Kämpfer, P., Makristathis, A., Lubitz, W. \& Busse, H.-J. (1996). Classification of bacteria isolated from a medieval wall painting. J Biotechnol 47, 39-52.

Altenburger, P., Kämpfer, P., Akimov, V. N., Lubitz, W. \& Busse, H.-J. (1997). Polyamine distribution in actinomycetes with group B peptidoglycan and species of the genera Brevibacterium, Corynebacterium, and Tsukamurella. Int J Syst Bacteriol 47, 270-277.

Brosius, J., Palmer, M. L., Kennedy, P. J. \& Noller, H. F. (1978). Complete nucleotide sequence of a $16 \mathrm{~S}$ ribosomal RNA gene from Escherichia coli. Proc Natl Acad Sci U S A 75, 4801-4805. 
Cerdà-Cuéllar, M., Rosselló-Mora, R. A., Lalucat, J., Jofre, J. \& Blanch, A. (1997). Vibrio scophthalmi sp. nov., a new species from turbot (Scophthalmus maximus). Int J Syst Bacteriol 47, 58-61.

Collins, M. D. \& Jones, D. (1980). Lipids in the classification and identification of coryneform bacteria containing peptidoglycans based on 2,4-diaminobutyric acid. J Appl Bacteriol 48, 459-470.

Cowan, S. T. \& Steel, K. J. (1974). Cowan and Steel's Manual for the Identification of Medical Bacteria, 2nd edn. Cambridge: Cambridge University Press.

Davis, M. J., Gillaspie, A. G., Jr, Vidaver, A. K. \& Harris, R. W. (1984). Clavibacter: a new genus containing some phytopathogenic coryneform bacteria, including Clavibacter xyli subsp. xyli sp. nov., subsp. nov. and Clavibacter xyli subsp. cynodontis subsp. nov., pathogens that cause ratoon stunting disease of sugarcane and Bermudagrass stunting disease. Int J Syst Bacteriol 34, 107-117.

Döpfer, H., Stackebrandt, E. \& Fiedler, F. (1982). Nucleic acid hybridization studies on Microbacterium, Curtobacterium, Agromyces and related taxa. J Gen Microbiol 128, 1697-1708.

Evtushenko, L. I., Dorofeeva, L. V., Subbotin, S. A., Cole, J. R. \& Tiedje, J. M. (2000). Leifsonia poae gen. nov., sp. nov., isolated from nematode galls on Poа аппиа, and reclassification of 'Corynebacterium aquaticum' Leifson 1962 as Leifsonia aquatica (ex Leifson 1962) gen. nov., nom. rev., comb. nov. and Clavibacter xyli Davis et al. 1984 with two subspecies as Leifsonia xyli (Davis et al. 1984) gen. nov., comb. nov. Int J Syst Evol Microbiol 50, 371-380.

Fox, J. G., Dewhirst, F. E., Tully, J. G., Paster, B. J., Yan, L., Taylor, N. S., Collins, M. J., Jr, Gorelick, P. L. \& Ward, J. M. (1994). Helicobacter hepaticus sp. nov., a microaerophilic bacterium isolated from livers and intestinal mucosal scrapings from mice. J Clin Microbiol 32, 1238-1245.

GCG (1995). Wisconsin Package Version 8.1 Program Manual. Madison, WI: Genetics Computer Group.

Gledhill, W. E. \& Casida, L. E., Jr (1969). Predominant catalasenegative soil bacteria. III. Agromyces, gen. n., microorganisms intermediary to Actinomyces and Nocardia. Appl Microbiol 18, 340-349.

Gordon, R. E., Haynes, W. C. \& Pang, C. H. N. (1973). The genus Bacillus. Agricultural Handbook no. 427. Washington, DC: US Department of Agriculture.

Groth, I., Schumann, P., Weiss, N., Martin, K. \& Rainey, F. A. (1996). Agrococcus jenensis gen. nov., sp. nov., a new genus of actinomycetes with diaminobutyric acid in the cell wall. Int $J$ Syst Bacteriol 46, 234-239.

Groth, I., Schumann, P., Rainey, F. A., Martin, K., Schuetze, B. \& Augsten, K. (1997). Bogoriella caseilytica gen. nov., sp. nov., a new alkaliphilic actinomycete from a soda lake in Africa. Int $J$ Syst Bacteriol 47, 788-794.

Helm, D., Labischinski, H., Schallehn, G. \& Naumann, D. (1991a). Classification and identification of bacteria by Fourier-transform infrared spectroscopy. J Gen Microbiol 137, 69-79.

Helm, D., Labischinski, H. \& Naumann, D. (1991b). Elaboration of a procedure for identification of bacteria using Fourier-transform IR spectral libraries: a stepwise correlation approach. J Microbiol Methods 14, 127-142.

Isenberg, H. D. (1992). Clinical Microbiology Procedures Handbook. Washington, DC: American Society for Microbiology.

Kämpfer, P., Steiof, M. \& Dott, W. (1991). Microbiological characterization of a fuel-oil contaminated site including numerical identification of heterotrophic water and soil bacteria. Microb Ecol 21, 227-251.

Lane, D. J. (1991). 16S/23S rRNA sequencing. In Nucleic Acid Techniques in Bacterial Systematics, pp. 115-175. Edited by E. Stackebrandt \& M. Goodfellow. Chichester: Wiley.

Lind, E. \& Ursing, J. (1986). Clinical strains of Enterobacter agglomerans (synonyms: Erwinia herbicola, Erwinia milletiae) identified by DNA-DNA-hybridization. Acta Pathol Microbiol Immunol Scand Sect B 94, 205-213.

Middendorf, L. R., Bruce, J. C., Bruce, R. C. \& 8 other authors
(1992). Continuous, on-line DNA sequencing using a versatile infrared laser scanner/electrophoresis apparatus. Electrophoresis 13, 487-494.

Moaledji, K. (1986). Comparison of Gram-staining and alternate methods, $\mathrm{KOH}$ test and aminopeptidase activity in aquatic bacteria: their application to numerical taxonomy. J Microbiol Methods 5, 303-310.

Osterhout, G. J., Shull, V. H. \& Dick, J. D. (1991). Identification of clinical isolates of gram-negative nonfermentative bacteria by an automated cellular fatty acid identification system. J Clin Microbiol 29, $1822-1830$

Park, Y. H., Suzuki, K., Yim, D. G. \& 7 other authors (1993). Suprageneric classification of peptidoglycan group B actinomycetes by nucleotide sequencing of 5S ribosomal RNA. Antonie Leeuwenhoek 64, 307-313.

Rainey, F., Weiss, N., Prauser, H. \& Stackebrandt, E. (1994). Further evidence for the phylogenetic coherence of Actinomycetes with group Bpeptidoglycan and evidence for the phylogenetic intermixing of the genera Microbacterium and Aureobacterium as determined by $16 \mathrm{~S}$ rDNA analysis. FEMS Microbiol Lett 118, 135-140.

Sasaki, J., Chijimatsu, M. \& Suzuki, K. (1998). Taxonomic significance of 2,4-diaminobutyric acid isomers in the cell wall peptidoglycan of actinomycetes and reclassification of Clavibacter toxicus as Rathayibacter toxicus comb. nov. Int J Syst Bacteriol 48, 403-410.

Schleifer, K. H. (1985). Analysis of the chemical composition and primary structure of murein. Methods Microbiol 18, 123-156.

Stackebrandt, E., Rainey, F. A. \& Ward-Rainey, N. L. (1997). Proposal for a new hierarchic classification system, Actinobacteria classis nov. Int J Syst Bacteriol 47, 479-491.

Suzuki, K., Sasaki, J., Uramoto, M., Nakase, T. \& Komagata, K. (1997). Cryobacterium psychrophilum gen. nov., sp. nov., nom. rev., comb. nov., an obligately psychrophilic actinomycete to accommodate "Curtobacterium psychrophilum" Inoue and Komagata 1976. Int J Syst Bacteriol 47, 474-478.

Takeuchi, M., Weiss, N., Schumann, P. \& Yokota, A. (1996). Leucobacter komagatae gen. nov., sp. nov., a new aerobic grampositive, nonsporulating rod with 2,4-diaminobutyric acid in the cell wall. Int J Syst Bacteriol 46, 967-971.

Tindall, B. J. (1990). Lipid composition of Halobacterium lacusprofundi. FEMS Microbiol Lett 66, 199-202.

Ventosa, A., Marquez, M. C., Kocur, M. \& Tindall, B. J. (1993). Comparative study of "Micrococcus sp." strains CCM 168 and CCM 1405 and members of the genus Salinicoccus. Int J Syst Bacteriol 43, 245-248.

Wayne, L. G., Brenner, D. J., Colwell, R. R. \& 9 other authors (1987). Report of the ad hoc committee on reconciliation of approaches to bacterial systematics. Int J Syst Bacteriol 37, 463-464.

Wieser, M. \& Busse, H.-J. (2000). Rapid identification of Staphylococcus epidermidis. Int J Syst Evol Microbiol 50, 1087-1093.

Wieser, M., Schumann, P., Martin, K., Altenburger, P., Burghardt, J., Lubitz, W. \& Busse, H.-J. (1999). Agrococcus citreus sp. nov., isolated from a medieval wall painting of the chapel of Castle Herberstein (Austria). Int J Syst Bacteriol 49, 1165-1170.

Zgurskaya, H. I., Evtushenko, L. I., Akimov, V. N., Voyevoda, H. V., Dobrovolskaya, T. G., Lysak, L. V. \& Kalakoutskii, L. V. (1992). Emended description of the genus Agromyces and description of Agromyces cerinus subsp. cerinus sp. nov., subsp. nov., Agromyces cerinus subsp. nitratus sp. nov., subsp. nov., Agromyces fucosus subsp. fucosus sp. nov., subsp. nov., and Agromyces fucosus subsp. hippuratus sp. nov., subsp. nov. Int J Syst Bacteriol 42, 635-641.

Zgurskaya, H. I., Evtushenko, L. I., Akimov, V. N. \& Kalakoutskii, L. V. (1993). Rathayibacter gen. nov., including the species Rathayibacter rathayi comb. nov., Rathayibacter tritici comb. nov., Rathayibacter iranicus comb. nov., and six strains from annual grasses. Int J Syst Bacteriol 43, 143-149.

Ziemke, F., Höfle, M. G., Lalucat, J. \& Rosselló-Mora, R. (1998). Reclassification of Shewanella putrefaciens Owen's genomic group II as Shewanella baltica sp. nov. Int J Syst Bacteriol 48, 179-186. 